\title{
Imagining Women: Cultural Representation of Women and Gender in Xhosa Radio Plays Pre-1994
}

\author{
Khaya Gqibitole \\ University of Zululand, Richards Bay, South Africa \\ Email:kgqibit@yahoo.com
}

How to cite this paper: Gqibitole, K. (2020). Imagining Women: Cultural Representation of Women and Gender in Xhosa Radio Plays Pre-1994. Open Journal of Social Sciences, 8, 265-277.

https://doi.org/10.4236/jss.2020.88022

Received: December 25, 2019

Accepted: August 21, 2020

Published: August 24, 2020

Copyright $\odot 2020$ by author(s) and Scientific Research Publishing Inc. This work is licensed under the Creative Commons Attribution International License (CC BY 4.0).

http://creativecommons.org/licenses/by/4.0/

\begin{abstract}
Apartheid was a deeply devastating system to the aspirations, dignity and human rights of black people. Apartheid, though, united them in their struggle for justice which culminated in the 1994 general elections. Despite the attainment of independence, though, black women still had to contend with another form of oppression-patriarchy. This study investigates stereotypical gender representation of women in Xhosa radio plays. The study used a qualitative approach and analyzed radio plays that were broadcast in the apartheid years. Two radio plays; Thamsanqa's Buzani Kubawo (ask father) and Kheswa's USomagqabi were analyzed in order to understand how women were written into the plays. Radio plays were decidedly gendered inappropriate and unapologetically biased towards men. In this regard, the study deployed the feminist poststructuralist theory and suggested possibilities for the attainment of women's emancipation in the new dispensation. It offered that women should challenge the plays' propagation of gender inequality that hinders women's equal rights by heeding Cixous' call that "woman must write woman". The double oppression of women because of their skin color and gender can only be defied when women themselves tell their own stories. Therefore, the study recommended gender-sensitive radio content and an inclusive staffing at the SABC so as to ensure that radio plays carry a transformative agenda that breaks gender stereotypes such as inequality, marginalization and oppressive marriages. The plays must champion socio-cultural realignment and promote equal education as well as meaningful involvement of women in decision making.
\end{abstract}

\section{Keywords}

Apartheid, Marginalization, Gender Inequality, Marriage, Radio Plays 


\section{Introduction: The Problem}

Media influences the society's perceptions and ideas about the world "out there". Radio, particularly, occupies a critical position in society regarding the dissemination of information. Because of its pervasive nature, its content can easily be construed as reality especially in traditional, illiterate communities. In such communities broadcast media is the bringer of truth. It is for this reason that radio can be lethal, as its role in the Rwandan genocide demonstrated in 1994. According to Kirschke (1996: p. 35.) the genocide was mainly incited by Radio Television Libres Des Mille Collines (RTLM) through the use of different indigenous languages. Professor Rene Degni-Segnui, the United Nations Special Rapporteur, reports that:

While broadcasts in French are inoffensive, those in Kinyarwanda are highly aggressive in tone. RTLM does not hesitate to call for the extermination of the Tutsi and it is notorious for the decisive role that it appears to have played in the massacre.

Equally, in oppressive countries such as apartheid South Africa, media content was designed to undermine black people in the guise of separate development. Even when the radio FM signal was extended to different black cultural groups on 25 December 1961, the content was used to achieve nefarious political ends. The Broederbond, the Afrikaner think-tank, deployed its spies to monitor radio content to ensure that the apartheid system was not undermined. Those who were planted for this purpose were Afrikaner men who were recruited from the farms because they were conversant in the local languages and so would be able to access material in indigenous languages. As insurance, subversion in radio plays was discouraged by demanding that the summary of the plays be written in Afrikaans. Another important requirement was that the play must use "pure Xhosa". Because language is the repository of culture, the use of "pure" indigenous languages achieved a number of goals; first it promoted the segregationist policy of apartheid; secondly, it created the myth that each tribal group was in control of its "own affairs"; thirdly and importantly for this study, romanticizing Xhosa tribal life only succeeded in entrenching patriarchy. A majority of the plays were written by males who promoted and reimagined Xhosa tribal life. The plays portrayed urban areas as dangerous and corruptible, a message that resonated with the influx control laws that sought to keep black people in "Black spots", away from white designated areas. Romance became the dominant theme in the plays, and in Xhosa tribal life romance means marriage and procreation, a similar "antilove" theme Cixous (1976: p. 878) writes about. To a large extent then, radio plays reflected the oppressive socio-cultural structure that held the aspirations of women in abeyance.

Radio plays promoted the sedentary domestic life of rural South Africa where women look after the household and children, at the expense of an inclusive society where women are encouraged to have a say in politics, religion, and be part of decision-making especially in matters concerning them. Able-bodied men 
were on the mines to raise lobola in order to start a family, so as to keep the conveyor belt of cheap labor going. In the few plays in which women are main characters, their powers are curtailed by either death, or insanity at the end of the play as if to forewarn audiences who harbor dreams and aspirations of challenging the status quo. Marriage was used to offset any aspirations that would see a woman transgressing predetermined socio-cultural "realities" of what it means to be woman. The paper, then, examines the ways in which women have been written into the plays in South Africa and elucidates how these plays tended to serve as well as perpetuate patriarchy. The paper argues that women were not only marginalized and treated as commodity, but were also denied full rights as citizens. The gendered social structure that was reinforced in the plays tended to be replicated in the lived lives of the audiences.

\section{Research Significance}

The study limits itself to the study of two Xhosa radio plays; Buzani Kubawo (1981) and USomagqabi (1986), as a case study into the depiction of women in the plays and suggests the way forward. The two plays which were produced by Mandla Myeko are not his original creations. One, Buzani Kubawo, was based on a well-known Xhosa novel while the other, USomagqabi, was first broadcast as a 30-minute play which he then serialized. The National Heritage Centre at Fort Hare University houses tapes and records of some of the Xosa plays and the rest are at the South African Broadcasting Corporation (SABC) archives in Port Elizabeth and Pretoria. Of the plays, only a handful of them were written by female playwrights. The current research may help in the rethinking, reshaping and calibration of radio plays in the new dispensation to promote equality between males and females. Radio is by far the most ubiquitous and easily accessible medium, especially in traditional societies whose only source of information is radio. Beulah Tshakweni confirms this in her 1970 letter:

You enable us to know world affairs. Some of us cannot read newspapers, but radio is there to help us. It is radio which enables us to know about heart transplants, space flights, wars in the Middle East, politics, and developments in our homelands. It also helps us with weather forecast.

That being the case then, the world created in the plays becomes the only lens through which audiences make sense of their lives. The content of radio plays always relegated women to the periphery of socio-political discourses. I argue that male playwrights failed to promote women since women were not in the core of decision making at the black radio stations. The restrictive power relations women experienced at home encroached onto radio content seamlessly, so much that radio content could easily influence their lived lives. The study can be used to examine whether there is a shift in the content of the plays post 1994. With the new constitution that promotes human rights, the emancipation of women and gender equality that should be uppermost in their programming. Most importantly, women should be encouraged to tell their own stories instead 
of being written into the stories men tell.

Theorists have deliberated on how gender equality can be achieved. While the current paper suggests resistance, theorists such as Deutsch (2007) believe the undoing of gender would result in gender equality, while resistance would only lead to entrenched positions. She is critical of West and Zimmerman's notion of "doing gender" because it invokes gender inequality and she instead proposes "undoing gender" which provides the elimination of gender roles. According to this, gender differences affect or influence interactions both at home and at the workplace because gender roles determine the power balance between sexes. As Deutsch (2007: p. 117) posits, "Men have more say, and they get more money, more attention, more interesting work, more status, and more leisure. Masculine pursuits are given greater value". It is for this reason that this study suggests that women should be given back their voices and space to participate in decision-making that would reshape social interactions and bring about gender equality.

\section{Theoretical Framework}

The emancipation of women could only happen if and when the old "realities" are challenged. Only challenging the tribal stereotypes and understanding the plight of women could lead to the emancipatory change. In order to explore possibilities of social change and emancipation, the study utilizes a feminist post-structuralism framework. In the plays the women are expected to subscribe to patriarchy. In line with theorists such as Helen Cixous, this view should be challenged, questioned and resisted. However, the reality created by male playwrights reinforces this in the plays dealt with. Writing is a powerful weapon, hence the audiences, a majority of which are illiterate, believe that the plays are the only truth, a position feminist post-structuralists challenge because there is no absolute truth but a range of possibilities. Dewar (1996: p. 6), for example, sums this well when she states:

I know myself through the stories I tell (each of these deeply imbricated in the other) and so I can choose, with others, to change the stories and to develop new ways of talking about them. Equally I can refuse discourses that speak me into existence in ways I no longer wish.

The empowerment of women to tell their stories would change the socio-cultural discourse that impedes their equitable participation in politics, workplace, and in social life. Women should be allowed space in which to construct and reconstruct their identities in order to make sense of themselves. In the apartheid era though, power was firmly in the hands of men, so women found themselves suppressed by both racism and patriarchy. The political and social circumstances hindered their "true" identities because, as Davies (1994: p. 513) puts it, " $(\mathrm{t})$ hat which we take to be natural is very hard to understand as social, and even harder to understand as a ritual whose significance lies in the maintenance of gender order". In apartheid South Africa rejecting and resisting 
the world created in the plays was almost impossible because of the inferior education given. In traditional Xhosa society education was not extended to women because theirs was marriage and childbearing. Illiteracy disempowers and exposes one to exploitation.

Feminism focuses on gender equality and rights which form the bedrock of women emancipation. Feminism as a movement is seized with uprooting subordination and suppression which, in our case, are promoted through the plays. To reverse notions of domesticity, gender sensitive policies must be formulated with the involvement of women. The plays elucidate the circumstances black women find themselves in and from which they need to be liberated. The tragic end of Thobeka in Buzani Kubawo, highlights the precarious situation in which women find themselves. The political and legal reforms men and women were fighting for in apartheid South Africa could benefit women; provided women have a say in those reforms. Dismantling the structure of society as promoted in the plays, is key to the attainment of equal rights. Therefore, in order to attain equality, issues such as reproductive rights, equal education, equal pay for equal work and political participation need attention.

\section{Burden of Womanhood Xhosa Radio Plays}

Radio plays imagine women as a homogenous group whose sole duty is in the domestic domain. This is not surprising since this was a reflection of women in apartheid South African whose status was a stay-at-home wife. It was for this reason that even the hated dompass that controlled the influx of men into urban spaces was not extended to women. Women were expected to remain home and raise a new crop of young men to work on the mines. Romance was almost always the main theme of the plays, and women still have little say in matters of love. In traditional societies expressions of love are a taboo. Marriage is the ultimate goal-an institution that strips women of any semblance of freedom. Even in instances where women are given lead roles in the plays, for instance, they still need to conform to the dictates of the society which curbs their individuality. To a large extent, the main function of marriage is the maintenance of social order and procreation. Any deviation from what is expected of a married woman brings chaos, not only to the homestead but to the nation as a whole. This is aptly demonstrated in AC Jordan's Ingqumbo Yeminyanya where the new wife, Thembeka, goes against culture resulting in a strife in the nation. Marriage is often used as a tool of control, so when it fails to do so with characters such as Thembeka disorder follows. Inevitable the woman is severely punished with insanity as it happens to Thembeka, being made invisible as is the case with $\mathbf{S o}$ magqabi in USomagqabi or even killed as it happens to Thobeka in Buzani Kubawo. Radio plays reinforce the notion amplified in Aidoo's (1987: p. 93) The Dilemma of the Ghost and Anowa that "a good woman does not have a brain or mouth".

In the Xhosa traditional culture, a girl goes through a ritual called intonjana, a 
rite of passage that teaches a girl how to behave as a wife or what Laws (1971) refers to as "housewifery". Those who fail to adhere to what they are taught at the intonjana, end up lamenting like Anowa when things turn sour in marriage. When this happens Anowa (Aidoo 1987: p. 112) cries out, "Someone should have taught me how to grow up to be a woman". That the ritual is an accepted practice plays a critical role in preparing the audience for what is to happen in the play. Theirs is to get affirmation of their expectations in a given social space. Any play that digresses from such projections is questionable. Audiences take issue with any content that seems to disrupt the order and normality of their society. As Radway (1984: p. 102) points out, "as the audience engage with the text, they reevaluate their lives by comparing themselves with the characters or their actions, thereby imbibing the social norms upheld in the text". Many audience members during this period were women since a bulk of men would be away for months on end on the mines. To a large extent then, the content was directed at women, because even the broadcast times favored the stay-at-home woman: $20 \mathrm{~h} 30$ and a repeat the following day at $13 \mathrm{~h} 30$. The home is traditionally the site of woman's everyday habitation. Hobson (quoted by Hall, 1980: p. 105) believes that radio has other important functions for the woman:

The radio, for the most part, is listened to during the day while they [women] are engaged in domestic labour, housework and child care ... In some cases, switching on the radio is part of the routine of beginning the day, it is, in fact, the first boundary in the working day. In terms of the "structurelessness" of the experience of housework, the time boundaries provided by radio are important in the women's own division of their time.

The content of the plays, therefore, echoed the value system of the society which promotes the idea that the man is the head of the family. Romance for its sake was frowned at, because such is reserved for marriage. However, the preservation of that purity doesn't guarantee a fulfilling married life for the woman. As Muhomah (2002: p. 77) avers:

The meaning of love and romance only becomes clear as the couple enters into married life. In the characterisations and interactions between the female and male protagonists before and after the exchange of marriage vows, they find out that romance and marriage may mean different things [emphasis added].

"Different things" may refer to deferred or even destroyed expectations and dreams as women enter the marriage institution. Marriage robs them of their independence, individuality and thought. Marriage becomes a death knell to their aspirations and dreams. Alluding to Davies (1994: p. 60), a woman has to conform to "societal prescriptions of what is appropriately female". Failure to adhere to such prescripts invites punishment of cataclysmic proportion.

\section{Woman Commodified in Xhosa Radio Plays}

Radio plays, as McQuail (1997: p. 96) suggests, "have always been gendered" and socially constructed based on the social context of the playwrights and the au- 
diences. Women have little room to maneuver themselves to new realities outside those constructs. The stereotypes run too deep to be changed outside of the writing process. The playwright is the master enforcer of the stereotypes which reflects his reality. In romance plays, the playwright determines the rules and controls the outcomes and patriarchy is the beneficiary in such an arrangement. The woman's life is predictable because she is groomed for marriage from a young age. Males hold the sway in the transaction that takes place between her family and her new home. What determines the father's acceptance of the suit is the wealth that would accrue to him through lobola, rather than a shared affection between the girl and would be husband. Women from both sides are just onlookers as men decide the worth of the girl. The size of the lobola is often decided by whether the girl is still a virgin as well as her level of education.

In order to satisfy and make her father happy then, chastity is paramount, hence the strict vigilance placed on the girl as she grows. She has to abide by strict rules to the point of self-effacement because she cannot independently pursue her dreams. In fact, older women in her family are expected to ready her for her new role as a wife, and in so doing becoming complicit in their oppression because, in the words of Cixous (1976: p. 878), "men have committed the greatest crime against women. Insidiously, violently, they have led them to hate women, to be their own enemies, to mobilize their immense strength against themselves, to be the executants of their virile needs". As is the case with Thobeka in Buzani Kubawo, trying to reason oneself out of the set-up is futile because culture demands conformity, the inverse invites the wrath of the ancestors. This echoing Aidoo's (1987) suggestion in Anowa that once married, a woman cannot think or speak. Romaine (1994: p. 101) reveals that "women and their speech have been measured against male standards and found to be deficient and deviant". Given that they can't speak or think, the least women can do is wait for instructions for the patriarch.

"Waiting" on the part of women is crucial in our understanding of their stagnated lives. Muhomah (2002: p. 77) asserts that "female protagonists and their virginity become a sight of waiting to be conquered". As suggested above, women are expected to preserve themselves and wait for "Mr Right" to conquer them-a "Mr Right" who may not be right for them or be of their choosing. Alluding to this, Cixous (1976: p. 877) states that "the little girls and their 'ill-mannered' bodies immured, well-preserved, intact unto themselves, in the mirror. Frigidified". It is clear that women do not have a say in their own sexuality once they enter the institution of marriage, theirs is to do as instructed by the husbands. The status of a woman in marriage is that of a junior partner, hence she takes a lead from her husband. The notion that the husband is the head of the family abounds in the plays. Ezeigbo (1997: p. 97) states that "gender conflicts appear to have been limited in traditional communities by socialization and educational practices, which encourage an acceptance of men as the polygynous heads of families, and the perception of women as the property of husbands". As property 
of the men, married women are expected to perform their main duty of extending the family name. It is crucial to note that a childless woman is never regarded as a real woman, less a wife.

In the Xhosa culture, in the event a husband dies, disappears or is diagnosed impotent the ritual of ukungenwa is invoked which entailed a male relative sleeping and impregnating her. This blatant violation illustrates the ownership of the woman's body. Writing about the objectification of women Romaine (1994: p. 127) says, “this is symbolic of women's position as men's property and represents their status as sex objects, whose availability or non-availability due to ownership by another male has to be marked in a conspicuous way". Molara Ogundipe-Leslie (cited in Davies: 1994: p. 68) posits this point succinctly when she notes that "the woman as a daughter or sister has greater status and more rights in her own lineage. Married, she becomes a possession, voiceless, and often rightless in her husband's family, except for what accrues to her through her children". This commoditization of women can easily be observed in Thamsanqa's play, Buzani Kubawo.

\section{Buzani Kubawo: Silence of the Lambs}

Arranged marriages are the worst form of oppression as they not only deny the woman the right to marry a man of her choice but also treat her as mere property. Such marriages are symbolic of the power relations that exist between men and women, where the latter is rendered a subhuman status. The catastrophe of arrange marriages is best illustrated in Thamsanqa's play Buzani Kubawo, published in a book form in 1958 and produced for the then Radio Xhosa by the late prolific playwright, Mandla Myeko. First broadcast was in 1981, the play was subsequently rebroadcast in 1988, 1993 and 1997 due to its popularity with the audience; this is in spite of the fact that the novel itself was initially prescribed for high schools. Its popularity, one can only speculate, can be located in its resonance with the socio-cultural practice of the audience and the graphic tragedy at the end.

The audience is introduced to a promising relationship between Gugulethu and NomaMpondomise. Gugulethu plans to marry his girlfriend, NomaMpondomise, however, unknown to both of them her parents are preparing to marry her away to a total stranger, Mcunukelwa who is on his way to pay lobola. To thwart the marriage Gugulethu has to cancel it out by paying an equal number of cattle to NomaMpondomise's family, but as fate would have it, his parents too are arranging a marriage between him and Thobeka he is not even acquainted to. His father, Zwilakhe, isn't deterred even when Gugulethu explains to him that he has already promised marriage to NomaMpondomise. After his marriage he is so distraught that he becomes insane. Upon reading about the marriage in a newspaper, NomaMpondomise takes him to court for breach of promise. In court the two reconcile and declare undying love for each other before NomaMpondomise commits suicide. Following this, Gugulethu runs away from 
home leaving "his young wife", Thobeka, behind. Five years later, Gugulethu's father, Zwilakhe, sends Thobeka and her three children born of Gugulethu's relative to Gugulethu. On the night they arrive he kills them in their sleep with an axe, before handing himself over to the police.

NomaMpondomise and Thobeka represent two sides of the same coin. On the one hand, NomaMpondomise tries to stand her ground by enlisting legal assistance. The legal system though has been found wanting with regards to women. Her suicide is akin to a cry for help, a recognition that the law is biased against women. Her suicide can also be seen as the ultimate punishment for those who resist culture. Her assertiveness disrupts social order and as such she must pay the ultimate price. Many strong women are forced to commit suicide, become insane or are accused of witchery in the plays.

On the other, Thobeka represents the epitome of wifehood-she is docile and ready to conform to culture. Her death cannot be aligned with her decisions but be blamed on Gugulethu. Critically though, both women are eliminated by the wielder of power, Gugulethu, whose act of brutality in killing Thobeka and her children should be understood as "the only way out". He is a symbol of men who can make and take life in line with the Burundian proverb, "a woman is only a passive earth, it is the man who provides the seed" (Berger, 2005: p. 149). Thobeka meekly accepts ukungenwa because to be a real wife she has to have children. Even her dying in sleep is symbolic of her voicelessness. As Lakoff avers, "women are communicative cripples" (Holloway, 1999: p. 132). As suggested above, a woman hides her true identity in order to be the model wife. As Alberts (cited in Berger, 2005: p. 148) puts it:

Unlike a man, a Rundikazi (Rundi woman) in public does not speak, nor does she look you in the eyes. To each question she answers Ndabizi? How should I know? In public, she lets it be thought that she knows nothing about politics, or where her husband is today, or even the wedding date of her daughter. She is the modest and obedient wife of her husband, the mother of her children, the conscientious mistress of her house, who is always working. Whatever she does, she does within the limits of her various feminine roles.

Give this; it is clear that independent, strong women must tone down for them to be acceptable in the society.

\section{USomagqabi: Wedlock Clutches}

Xhosa radio plays have had a fair share of feisty and self-assured women as lead characters. One such character is Somagqabi in Kheswa's USomagqabi. Strong-willed and influential women are sometimes shunned in the community and treated like an oddity because they challenge the status quo and sometimes threaten the masculinity of men. As Laws (1971) maintains, in families with a working wife there is comparable less husband domination. Owing to their characters, men sometimes avoid marrying them, plunging them in a quagmire where they are given demeaning labels such as spinsters, witches, poison before being isolated. 
Somagqabi, the lead character in the play, is treated in the similar way. The play re-enacts the sometimes disputed historical movement of the Nguni people from Northern Africa to Southern Africa. First broadcast as a 30-minute play, it was serialized by Mandla Myeko and broadcast in 1986. Battles over land and livestock were the order of the day and Somagqabi demonstrates her prowess and leadership qualities in this movement. Leaders such as Xhosa and Zulu take notice of her skills which far surpasses theirs. Unknown to the male leaders, Somagqabi gets her powers from a spear she was given by an old woman in the forest. The spear gives her supernatural powers, makes her invincible and gives her powers of a seer. These capabilities enable her not only to defend her warriors but to also increase their numbers; making the other male leaders jealous and apprehensive of her.

A plan is hatched to kill all older women who are accused witchery and Somagqabi is included in the accused. Her romantic involvement with Xhosa, though, saves her and the other leaders are asked to speak to her instead. This, in itself is a break from the norm where women are normally ordered about and never consulted on matters of state. After deliberations, a deal that is meant to expose her femininity and thus undermine her leadership status is struck when she is given the difficult task of executing the accused. This is in line with what Deutsch (2007: p. 118) notes when she argues that, "even when women make inroads into a particular field, that field becomes feminized and subsequently devalued". Instead of killing the condemned though, unknown to others, she hides them in a cave. When the killing is called off, the condemned are drafted in her warriors. When the Nguni people arrived in southern Africa they split into different kingdoms with the blessing of the ageing king Nguni. Xhosa and Somagqabi settle in the present day Eastern Cape and form the Xhosa kingdom.

After Xhosa had established his kingdom, Somagqabi is stripped of her position of power in a rather typical but predictable manner-marriage. At first she refuses to get married because she remembered the words of the old woman who gave her the spear. Her warning was clear; she should never marry. The old woman sounds as though she fears marriage but it would seem marriage is inevitable for Somagqabi just like Thobeka and NomaMpondomise in Buzani Kubawo. Just like all women, she is damned if she doesn't accede to marriage, and damned if she does. Paradoxically, even though she is not bound by the dictates of the living, the old woman still observes the power of patriarchy. She says to Somagqabi:

Ungaze wende Somagqabi nokuba umfana sele umthanda kangakananina, kuba uyakuphulukana nawo la mandla sikunika wona. Mhla lafika ithuba lakho lokwenda uyakuva nawe emzimbeni ukuba lifikile, wandule ke wende. Xa lingekafiki ungangxami uziphose kuko.

(Never marry Somagqabi even if you are in love because you will lose the power we give you. When the time comes for you to marry, your body will tell you, and then you can get married. Do not rush into it.) 
Despite this veiled warning, Somagqabi agrees to the marriage and just like Anowa, she becomes just like any other woman ... "for she was made to believe that a well-adjusted normal woman has a ... divine composure" (Cixous, 1976: p. 876). Once married she surrenders her life to her husband because marriage enforces gender subordination. In the transit space she is accorded qualities of a man, but marriage makes her ordinary. Through the transit space she is presented as someone whose horizon is unlimited but marriage tames her. After her domestication she has to observe the rules of her station as a wife. To a large extent, the marriage institution redefines her identity and weakens her powers while her husband, Xhosa, is given leverage not only to control but to dominate her. Articulating the same view, Davies (1994: p. 63) suggests that "domination installs power relations between groups and seeks to maintain this domination through a control of the sense-making devices". In this sense marriage is used to restore order through stripping Somagqabi of any semblance of power. Like many women in her situation, she is left to lament, "What happiness for us who are omitted, brushed aside at the scene of inheritance" (Cixous, 1976: p. 878). Somagqabi cannot remain a spinster; she has to exchange her powers for marriage in order to restore normality. As a spinster she represents a destructive force or as Davies (1994: p. 63) puts it "a figure of feminist possibility" but as a wife she is a servant of peace. She is rendered docile and ready to serve her husband's desires.

In Asante, on the Gold Coast, Allman (2005: p. 201) reports a sinister decision by a chief who, in the 1930s, decreed that unattached spinsters should be rounded up and jailed unless they pointed out someone who would marry them. Coupled with the arrests, these spinsters, once married, had to buy clothes for their husbands. Like other women then, Somagqabi has to avoid becoming idikazi (spinster) because traditional societies have very low regard for such women. Using and representing women as cash cows abounds in many radio plays. The politics of marriage is essentially the politics of wealth and exploitation on which patriarchy thrives. Women are not only seen as sources of income for the father, as suggested above, they also generate wealth for their husbands. They are expected to be supportive of their husbands at all times. Writing about the Swahili Popular Drama, Lange (2002: p. 9) makes a similar point when she asserts that "since the plays are firmly rooted in patriarchal ideology ... the only space left for a 'good' woman is to be supportive of her husband through thick and thin".

In the play, Somagqabi, Xhosa benefits from his wife's foresight in ensuring the growth of his warriors making it possible to form a formidable kingdom. The wealth she amasses in terms of human capital equals or even surpasses economic wealth anticipated of women. Many radio plays make it abundantly clear what the husband expects from his wife. In Uyinkulu Kabani, for instance, Madliwa kills his bed-ridden, illiterate wife accusing her of laziness. This is in spite of the fact that he, as the eldest son, is averse to work and only awaits the death of his 
father so that he can inherit everything. In addition, he is secretly interested in marrying an educated, urban woman who would bear him a son. One can surmise here that the purported laziness of his wife has nothing to do with her state of health other than that she cannot bear him a son. Again, and ironically, women are depicted as useful only if they benefit and fulfill the needs of men. It is clear that women are marginalized, dominated and even sacrificed in radio plays. While some women are given lead roles, like Somaqgabi, by the end of the play they have to be put in their place. Similarly, Newton (1981: p. 8), writing about novels, says:

The heroine's power is sometime renounced and often eliminated at the end of the novel, so that it seems that the work has had nothing to do with power at all. For no matter how much power the heroine is granted at the beginning of the story, ideology as it governs life and it governs literary form, requires that she should marry, and marriage means relinquishing of power as surely it means the purchase of wedding clothes.

As indicated above, among a plethora of constricting tools that have been used to subjugate women, marriage seems to be a central cog. While girls initially seem to be free, independent and can dream; once they marry they are expected to uphold culture and tradition which diminish their rights. Those who fail to follow suit are either labeled madwomen, witches or seen as deviant.

\section{Conclusion}

Cixous' poignant call that "( $\mathrm{w})$ oman must put herself into the text-as into the world and into history-by her own movement" is a critical one. It is only when women realize the "immense strength" and use it to uplift themselves that they will regain their dignity, and dismantle patriarchy. Writing themselves into the world would release them from the bondage inscribed in their stories by men. While their bodies have been scarred by years of oppression dispensed by racism and patriarchy, their future is pregnant with possibilities the likes of Somagqabi has charted for them. The medium of radio is not only pervasive; it is also powerful and hence influencing its content is tantamount to being a creator. Creating the world of the play has immense implication for the audience whose sole source of information may be the radio. In order to free women of the oppressive tradition, playwrights, men or women, should imagine a “... woman who would hold out against oppression, and constitute herself as superb, equal, hence 'impossible' subject, untenable in a real social framework". The post-independence female character in the plays must be the "impossible subject" who refuses to be tamed by "housewifery". Pliable characters such as Thobeka, need playwrights who would make them appreciate their worth and claim their place in the world. It is precisely in radio plays that gender roles should be renegotiated in order to achieve equality. Dismantling gender inequality is possible because "gender is not something we are, but something we do. Gender must be continually socially reconstructed in light of 'normative conceptions' of 
men and women" (Deutsch, 2007: p. 106).

\section{Conflicts of Interest}

The author declares no conflicts of interest regarding the publication of this paper.

\section{References}

Aidoo, A. A. (1987). The Dilemma of a Ghost and Anowa. New York: Longman.

Allman, J. (2005). Rounding Up Spinsters: Gender Chaos and Unmarried Women in Colonial Asante. In A. Cornwell (Ed.), Readings in Gender in Africa (pp. 195-214). Oxford: James Currey.

Berger, I. (2005). Rebels or Status Seekers? Women as Spirit Mediums in East Africa. In A. Cornwall (Ed.), Readings in Gender in Africa (pp. 148-156). Oxford: James Currey.

Cixous, H. (1976). The Laugh of the Medusa. Signs: Journal of Women in Culture and Society, 1, 875-893. https://doi.org/10.1086/493306

Davies, C. B. (1994). Other Tongues: Gender, Language, Sexuality and Politics of Location. In Black Women, Writing and Identity (pp. 152-165). London: Routledge.

Deutsch, F. M. (2007). Undoing Gender. Gender and Society, 21, 106-127. https://doi.org/10.1177/0891243206293577

Dewar, T. D. (1996). Women and Graduate Adult Education. http://www.calliopelearning.com/diss/six.html

Ezeigbo, T. A. (1997). Gender Conflicts in Flora Nwapa's Novels. In S. Newell (Ed.), Writing African Women: Gender, Popular Culture and Literature in West Africa (pp. 95-104). London: Zed.

Hall, S. W. (1980). Encoding/Decoding. In S. Hall, D. Hobson, A. Lowe, \& P. Willis (Eds.), Culture, Media, Language: Working Papers in Cultural Studies (pp. 63-87). London: Hutchinson.

Holloway, M. et al. (1999). Selves and Others. Cape Town: Oxford University Press.

Kheswa, D. (1986). USomagqabi. Port Elizabeth: Umhlobo Wenene FM, Parsons Hill.

Kirschke, L. (1996). Broadcasting Genocide: Censorship, Propaganda and State-Sponsored Violence in Rwanda 1990-1994. Article 19, London.

Lange, S. (2002). Gender Discourse in Swahili Popular Drama: Negotiating Official and Popular Ideologies. In the ASA Conference.

Laws, J. L. (1971). A Feminist Review of Marital Adjustment Literature: The Rape of Locke. Journal of Marriage and Family, 33, 483-516. https://doi.org/10.2307/349848

McQuail (1997). Audience Analysis. London: Sage.

Muhomah, C. (2002). What Do Women Want? Versions of Masculinity in Kenyan Romantic Fiction. English in Africa, 45, 77. https://doi.org/10.1080/00138390208691316

Newton, L. J. (1981). Women, Power and Subversion. New York: Methuen.

Radway, J. A. (1984). Reading the Romance: Women, Patriarchy, and Popular Literature. Chapel Hill, NC: University of Carolina.

Romaine, S. (1994). Language and Society. An Introduction to Sociolinguistics. Oxford: Oxford University Press.

Thamsanqa, W. K. (1981). Buzani Kubawo. Port Elizabeth: Umhlobo Wenene FM, Parsons Hill. 